\title{
The Concept and Model of Restorative Justice Integration in the Crime of Defamation
}

\author{
Amriyanto $^{1}$ M. Syukri Akub ${ }^{2}$ Muhadar $^{2} \quad$ Nur Azisa $^{3}$ \\ 1. Doctoral Student, Faculty of Law, Hasanuddin University, Indonesia \\ 2.Professor of Law, Faculty of Law, Hasanuddin University, Indonesia \\ 3.Associate Professor, Faculty of Law, Hasanuddin University, Indonesia
}

\begin{abstract}
The concept of Restorative Justice in the Indonesian criminal justice system is an interesting study and analysis, because so far various writings have only seen settlements through Restorative Justice as the settlement of cases outside the judiciary. This study uses a normative method with an approach to legislation and concepts as well as the use of the main legal sources from the results of the dissertation study. The results of the study indicate that regulatory aspects of criminal case settlement in Indonesia have existed through sectoral regulations of the police and prosecutors. There have been many implementations of the settlement of criminal cases through Restorative Justice, especially regarding the crime of defamation as a crime complaint. The settlement of crimes of defamation through Restorative Justice has provided protection for victims. The concept of protecting victims of defamation crimes is the legal interest of the victim, forgiveness, harmonization of the relationship between the victim and his/her treatment and family as well as the restoration of the victim's social environment. The integration model for the settlement of the crime of defamation is carried out through a peace agreement between the victim and the perpetrator which is followed up through the termination of the investigation or prosecution of the case. In court, the settlement through Restorative Justice is used as the basis for judge's consideration in mitigating sentences in the form of probation. Internal supervision through the leadership of law enforcement agencies and external supervision through pretrial is a means of controlling the integration of Restorative Justice in the Indonesian criminal justice system.
\end{abstract}

Keywords: Restorative Justice, Crime of Defamation, The Indonesian Criminal Justice System.

DOI: $10.7176 / \mathrm{JLPG} / 116-02$

Publication date: December $31^{\text {st }} 2021$

\section{A. Introduction}

Crime resolution through restorative justice (RJ) is a crime resolution model that focuses on the participation of victims and perpetrators and their families, the needs of the victims, and the responsibility of the perpetrators. ${ }^{1}$ This concept is different from solving crimes through retributive justice which focuses on punishment, because punishment is the right way to achieve redress, although it is recognized that there are alternatives. ${ }^{2}$ In Indonesia, RJ has only been known since the enactment of the 2012 juvenile criminal justice system law through the concept of diversion ${ }^{3}$, in the world this model is rooted in the practice of indigenous peoples starting in Canada in the $1970 \mathrm{~s} .{ }^{4}$

In 2019 there were 1,500 cases of defamation through electronic means in Indonesia and in 2020 there were 1,794 cases. $^{5}$ The data from the South Sulawesi Regional Police (Polda) in 2018 were 204 cases of defamations, and 3 cases were completed through RJ. In 2019 there were 325 defamation cases, and 156 cases were completed through RJ. In 2020 there were 231 defamation crimes, and 119 cases were completed through RJ. ${ }^{6}$ Data from the Attorney General's Office for the Year 2020 - August 2021 were 304 criminal cases resolved through RJ. ${ }^{7}$ Data on the decisions of the Makassar District Court and High Court in 2018 contained 1 case each. ${ }^{8}$ There are 68 cases of contempt of high court decisions in Indonesia in 2018 as many as 68 cases. ${ }^{9}$ While in the District Courts throughout Indonesia as many as 122 cases. ${ }^{10}$ In the Supreme Court during 2018 there were

\footnotetext{
${ }^{1}$ Zehr, H. (2015). The little book of restorative justice: Revised and updated. Simon and Schuster. Pennsylvania: Intercourse. p. 21

${ }^{2}$ Von Hirsch, A., Roberts, J. V., Bottoms, A. E., Roach, K., \& Schiff, M. (Eds.). (2003). Restorative justice and criminal justice: Competing or reconcilable paradigms. Bloomsbury Publishing. p.44

${ }^{3}$ Bakhtiar, H. S., Sofyan, A. M., \& Haeranah, H. (2019). Criminal Justice System of Children in Indonesia. IOSR Journal Of Humanities And Social Science (IOSR-JHSS) Volume, 24, 01-07.

${ }^{4}$ Britto, S., \& Reimund, M. E. (2013). Making space for restorative justice in criminal justice and criminology curricula and courses. Contemporary Justice Review, 16(1), 150-170. https://doi.org/10.1080/10282580.2013.769301.

https://kabar24.bisnis.com/read/20210310/16/1366254/polri-pelaporan-uu-ite-cenderung-meningkat-sejak-20182020\#: :text=Selain\%20itu\%2C\%20Polri\%20mencatat\%20kasus, $1.794 \% 20$ laporan\%20polisi\%20pada\%202020. Accessed on 28 april 2021

${ }^{6}$ Directorate of General Crime and Investigation of the South Sulawesi Regional Police, 2021.

${ }^{7}$ ST. Burhanuddin. (2021). Hukum Berdasarkan Hati Nurani (Sebuah Kebijakan Penegakan Hukum Berdasarkan Keadilan Restoratif).

Pidato Pengukuhan Guru Besar Tidak Tetap Universitas Jenderal Soedirman. Purwokerto. (10 September 2021). p. 18.

${ }^{8}$ Makassar High/State Court, 2018, Makassar High Court Annual Report 2018.

${ }^{9}$ Supreme Court of the Republic of Indonesia, 2018, Supreme Court Annual Report 2018, p. 98.

${ }^{10}$ Supreme Court of the Republic of Indonesia, p. 110.
} 
49 cases. Specifically for the crime of defamation, RJ faced various challenges, namely issues related to definition, institutionalization, displacement and relevance. ${ }^{1}$

RJ's presence comes from criticism of the practice of retributive justice. ${ }^{2}$ RJ's relationship with retributive justice is always debated ${ }^{3}$, but there are strong reasons to find a complement in the implementation of these two processes ${ }^{4}$ and there are thoughts of restructuring the criminal justice system, especially in South Australia by integrating RJ. ${ }^{5}$ In the UK RJ has been implemented in the criminal justice system ${ }^{6}$, but still gets the main support from a very large and powerful judicial institution to run RJ. ${ }^{7}$ Globally, RJ is increasingly influencing the thinking of criminal justice policy-making and even RJ's rules are used as a catalyst to reform the entire criminal justice system. ${ }^{8}$ In Uruguay, RJ was used as a rationale for comprehensive reform of the criminal justice system. ${ }^{9}$ So far, there have been various ideas for integrating the principles of RJ into the criminal justice system and this has made significant progress, both in terms of reparations and access to justice for victims and has even expanded the use of RJ in every stage of the criminal justice process. ${ }^{10}$ In Nigeria due to the failure of the criminal justice system, the idea of integrating RJ into the criminal justice system ${ }^{11}$ by Dignan and Lowey as a model of full integration emerged. ${ }^{12}$ The integration of RJ into the criminal justice system is determined by 3 (three) factors, namely rule enforcement, creating a professional culture and institutional support. ${ }^{13}$

The current Indonesian criminal justice process with the RJ model has experienced various problems, because various correctional institutions have experienced over capacity ${ }^{14}$ and the development of ideas related to access to justice and the needs of victims that cannot be answered in retributive justice. ${ }^{15}$ The paradigm shift towards RJ as a solution to overcome these problems. This article offers a design model for RJ's integration into the Indonesian criminal justice system, particularly in relation to crimes of defamation or defamation as crimes of complaint. In addition, the author offers the idea of controlling the implementation of RJ in the Indonesian criminal justice system. The method used by the author in this article is a normative method, with a statutory and conceptual approach. The main legal materials used are the results of the author's dissertation research at the Faculty of Law, Hasanuddin University, Makassar Indonesia, statutory regulations and references.

\section{B. Analysis and Discussion}

a) Retributive and Restorative

Retributive views crime as a violation of the state ${ }^{16}$ or the state's ${ }^{17}$ domain as a violation of the law and the state as a victim ${ }^{18}$, thus giving birth to ius puniendi or even officium puniendi. ${ }^{19}$ Crime is born, because the state fails

\footnotetext{
${ }^{1}$ Wood, W. R., \& Suzuki, M. (2016). Four challenges in the future of restorative justice. Victims \& Offenders, 11(1), 149-172. https://doi.org/10.1080/15564886.2016.1145610.

${ }^{2}$ Zehr, H. (1990). Changing Lenses: A New Focus for Crime and Justice Harrisonburg, VA.

${ }^{3}$ Zedner, L. (1994). Reparation and retribution: Are they reconcilable. Mod. L. Rev., 57, 228.

${ }^{4}$ Hermann, D. H. (2017). Restorative justice and retributive justice: An opportunity for cooperation or an occasion for conflict in the search for justice. Seattle J. Soc. Just., 16, 71.

${ }^{5}$ Smith, A. (2013). Mainstreaming Restorative Justice in South Australia's Criminal Justice System: A Response to the Over-Representation of Indigenous Offenders. The ANU Undergraduate Research Journal, 169.

${ }^{6}$ Marder, I. D. (2018). Restorative justice and the police: exploring the institutionalisation of restorative justice in two English forces. thesis the degree of Doctor of Philosophy, The University of Leeds School of Law Centre for Criminal Justice Studies Centre for Law and Social Justice, (Februari 2018).

${ }^{7}$ Dignan, J., \& Marsh, P. (2001). Restorative justice and family group conferences in England: current state and future prospects. Restorative Justice for Juveniles Conferencing, Mediation and Circles, 85-101. p.86

${ }^{8}$ Dignan, J. (2012). Restorative justice and the law: the case for an integrated, systemic approach. In Restorative justice and the law (pp. 188210). http://www.antoniocasella.eu/restorative/Dignan_2002.pdf.

${ }^{9}$ Palermo, P. G., del Castillo, F., \& Fraiman, R. (2019). Restorative Justice in Uruguay: A Change of Lenses in a Reform of Criminal Justice?. European Journal for Security Research, 4(1), 131-147.

10 ICCLR, (2020), Restorative Justice Principles and the Criminal Justice Process, https://icclr.org/2020/05/25/restorative-justiceprinciples-and-the-criminal-justice-process/, accessed on 18 April 2021.

${ }^{11}$ Olayode, A. (2017). Back to the Past: The (Re) Integration of Restorative Justice into the Nigerian Criminal Justice System..

${ }^{12}$ Dignan, J., \& Lowey, K. (2000). Restorative justice options for Northern Ireland: A comparative review. Belfast: Stationery Office. p. 4956

${ }^{13}$ Dignan, J., \& Marsh, P. p.87, n.10

${ }^{14} \mathrm{http}: / / \mathrm{sdp}$.ditjenpas.go.id/sdp website/, accessed on 20 April 2021.

15 Wemmers, J. A., \& Cyr, K. (2004). Victims' perspectives on restorative justice: How much involvement are victims looking for?. International Review of Victimology, 11(2-3), 259-274. See also, Bakhtiar, H. S., \& (2015). Penerapan Sanksi Pidana dan Tindakan Terhadap Anak Menurut UU No. 11 Tahun 2012 Tentang Sistem Peradilan Pidana Anak. Universitas Muslim Indonesia.

${ }^{16}$ Dzur, A. W., \& Olson, S. M. (2004). The value of community participation in restorative justice. Journal of social philosophy, 35(1), 91107.

${ }^{17}$ Wenzel, M., Okimoto, T. G., Feather, N. T., \& Platow, M. J. (2008). Retributive and restorative justice. Law and human behavior, 32(5), 375

${ }^{18}$ Poplawsky, J. P. (2017). Learning to Heal: The Impact of a Restorative Justice Program on Crime Victims. Doctor of Philosophy University of The Incarnate Word. p.6.

${ }^{19}$ Maculan, E., \& Gil Gil, A. (2020). The Rationale and Purposes of Criminal Law and Punishment in Transitional Contexts. Oxford Journal of Legal Studies, 40(1), 132-157.
} 
to protect its citizens and the state is obliged to bear the risk for its failure. ${ }^{1}$ The retributive focus is on punishing the offender ${ }^{2}$ and establishing the guilt of the offender who creates guilt by administering a painful punishment. ${ }^{3}$ The idea of retributive was born from the ideas of Kant and Hegel who saw punishment for balance ${ }^{4}$, vengeance as an aesthetisch from Herbart ${ }^{5}$ and vengeance as a divine teaching to create the common good from Aquino ${ }^{6}$.

Wrong people must suffer for their mistakes and must be proportionate, Kant calls moral necessity and Hart calls punishment justification. Kant's ideas are questioned regarding the relationship between wrongdoing and suffering. ${ }^{7}$ The question is answered with a utilitarian approach that wrongdoers do not always have to suffer the consequences of their mistakes, because they can be forgiven. ${ }^{8}$

Hart's retributive idea sees punishment on 3 (three) principles, namely (a) a person is punished, if he commits a voluntary mistake; (b) the penalty must be proportionate to the offense committed; (c) people are punished for suffering for the crime committed (justification of punishment). ${ }^{9}$ Bedau states that Hart's retributive is not a complete theory of punishment, because it is unable to answer all questions related to the theory and practice of punishment. ${ }^{10}$ Brown said Kant and Hegel had failed to prove that punishment was the right mechanism to restore balance. ${ }^{11}$ The idea of retributive in looking at crime and how to overcome it has received various criticisms and is even considered obsolete. ${ }^{12}$

RJ's notion of seeing crime as a violation of the individual/person relationship. ${ }^{13}$ Crime is not only a violation of the law, but also against people and relationships ${ }^{14}$ Crime is seen as a conflict between community members, so they resolve it in their own way such as making peace between the conflicting parties. ${ }^{15}$ Conflicts belonging to victims and violators and other parties must participate, but law enforcement steals or robs and declares it their rights and obligations ${ }^{16}$. The primary focus of restorative therapy is healing ${ }^{17}$ and improvement ${ }^{18}$, not punishment.

One of the reasons the state imposes retributive punishments is to protect the interests of state law and the nature of criminal law as a public law, but when the crime that occurs is an individual crime, it is related to the honor and reputation of the individual. The state can put aside its interests and leave it to the victim to choose restorative or retributive. The state is obliged to provide that space, so that victims can choose it. However, it is different when punishment is seen as an obligation of the state and only as a right for the victim. ${ }^{19}$ The debate in that direction is interesting to discuss. ${ }^{20}$ The author is of the view that the interests of the state can be sidelined when the crimes committed are individual crimes and there are alternative ways to fulfill better justice.

The perspective of retributive justice and RJ towards crime is different, causing the way of settlement and the goals to be achieved are different. RJ's goal is reparation and retributive justice is punishment, where punishment can hinder recovery. ${ }^{21}$ The author does not debate the two or rule out one of them, but the author tries to see that RJ is an alternative choice in a retributive justice criminal justice system. Both can be integrated and parallel in one system and complement each other's shortcomings. The idea of RJ's integration of the crime

\footnotetext{
${ }^{1}$ Azisa, N. (2015). Kompensasi Dan Restitusi Bagi Korban Kejahatan Sebagai Implementasi Prinsip Keadilan. Disertasi Program Pascasarjana Universitas Hasanuddin. Makassar, p. 174-175.

${ }^{2}$ Witvliet, C. V., Worthington, E. L., Root, L. M., Sato, A. F., Ludwig, T. E., \& Exline, J. J. (2008). Retributive justice, restorative justice, and forgiveness: An experimental psychophysiology analysis. Journal of Experimental Social Psychology, 44(1), 10-25.

${ }^{3}$ Poplawsky, J. P. Ibid.

${ }^{4}$ Brown, S. P. (1998). The moral justification of retributive punishment by reference to the notion of balance, University of Sheffield. p.ii

${ }^{5}$ Oppenheimer, H. (1913). The rationale of punishment (Vol. 1). Thesis approved for the degree of Doctor of Literature in the University of London, The University of London Press, Ltd. By Hodder and Stoughton, Warwick Square, E.G. 1913, p. $221-224$

${ }^{6}$ Koritansky, P. (2005). Two theories of retributive punishment: Immanuel Kant and Thomas Aquinas. History of Philosophy Quarterly, 22(4), 319-338. http://www.jstor.org/stable/27745035

${ }_{7}$ Hill, T. E. (1999). Kant on wrongdoing, desert, and punishment. Law and Philosophy, 407-441. http://www.jstor.org/stable/3505232

${ }^{8}$ Ibid.

${ }^{9}$ Hart, H. L. A. (2008). Punishment and responsibility: Essays in the philosophy of law. Oxford University Press. p. 231.

${ }^{10}$ Bedau, H. A. (1978). Retribution and the Theory of Punishment. The Journal of Philosophy, 75(11), 601-620.

${ }^{11}$ Brown, S. P. Op Cit.

${ }^{12}$ Bedau, H. A. Op Cit

${ }^{13}$ Wilson, D. B., Olaghere, A., \& Kimbrell, C. S. (2018). Effectiveness of restorative justice principles in juvenile justice: A meta-analysis. Inter-university Consortium for Political and Social Research.

${ }^{14}$ Llewellyn, J. (2013). Truth commissions and restorative justice. In Handbook of restorative justice (pp. 373-393). Portland, OR: Willan Publishing.

${ }^{15}$ Johnstone, G. (2013). Restorative justice: Ideas, values, debates. Routledge. Published Willan Publishing, Culmcott House, Mill Street, Uffculme Cullompton, Devon, p. 12.

16 Christie, N. (1977). Conflicts as property. The British journal of criminology, 17(1), 1-15. https://doi.org/10.1093/oxfordjournals.bjc.a046783

${ }^{17}$ Edgar, K., \& Newell, T. (2006). Restorative justice in prisons: A guide to making it happen. Waterside Press.

${ }^{18}$ Lloyd, A., \& Borrill, J. (2020). Examining the effectiveness of restorative justice in reducing victims' post-traumatic stress. Psychological injury and law, 13(1), 77-89. https://doi.org/10.1007/s12207-019-09363-9

${ }^{19}$ Akub, M. S., \& Asis, A. (2020). Perlindungan Hukum Terhadap Saksi Pelapor dalam Tindak Pidana Korupsi. Amanna Gappa, Vol. 28 No. 2, 2020 .

${ }^{20}$ Maculan, E., Op.Cit.

${ }^{21}$ Von Hirsch, et.al. Op.Cit.
} 
of defamation is the focus of the author's study and analysis in this article.

\section{b) Crime of Defamation}

Each country assesses defamation or defamation crimes differently. United States, United Kingdom, Canada (with the exception of Quebec) use the plural system (criminal and civil), Australia and Ireland defamations are civil matters. In Germany, Austria, the Netherlands, Denmark, France, Italy, Greece, Portugal, Japan and Spain, defamation is a criminal offence. ${ }^{1}$ The UK (defamation act 2013), Australia (defamation act 2005), Singapore (defamation act 2005), and Malaysia (defamation act 1957) have defamation laws. Defamation in the Indonesian legal system ${ }^{2}$ also uses a plural system (criminal Article 310-318 of the Criminal Code, Articles 27 (3), 45 (3) of the Electronic Information and Transactions Law and civil articles 1365, 1372 of the Law on Electronic Information and Communication Civil). There are many other arrangements regarding the crime of defamation, but in this paper only defamations against a person or individual. This paper focuses on defamation or defamation as a crime.

Anstey questioned the existence of defamation in criminal law because of freedom of expression. ${ }^{3}$ The author's opinion that Indonesia as a civilized country and as part of the ideology of the state, is very important to maintain the honor and reputation of individuals. The placement of the crime of defamation or defamation as a complaint offense is appropriate, because the prosecution of this crime is determined by the will and will of the victim.

Police statement that the number of cases of defamation or defamation through electronic means in Indonesia in 2019 was 1,500 cases and in 2020 there were 1,794 cases ${ }^{4}$. The police, through telegrams, prioritize the resolution of cases of defamation or defamation through restorative justice. ${ }^{5}$ Data from the South Sulawesi Police (Indonesia) in 2016 as many as 263 cases of defamations, in 2017 as many as 423 cases of defamations, in 2018 as many as 204 cases of defamations, in 2019 as many as 325 cases of defamations, in 2020 as many as 231 cases of defamations. ${ }^{6}$ Court data in 2018 was 122 cases and the remaining cases in 2017 were 35 cases. Of these cases, 136 cases were decided. High court data in 2018 the number of cases examined and tried was 68 cases and the remaining cases in 2017 were 8 cases. Of the total number of cases of criminal offenses of defamation that were decided at the high court level throughout Indonesia as many as 62 cases.

The appearance of defamation as a crime is part of the state's protection of one's honor or by Veeder as a protection of reputation. ${ }^{7}$ The crime of defamation in Indonesian criminal law is a crime of complaint and complaint as a condition of prosecution. Prosecution of a crime complaint depends on the consent of the victim of the crime and the victim can withdraw his complaint if there has been peace between the perpetrator and the victim. ${ }^{8}$ The crime of complaint is an exception to the consequences of the public law nature of criminal law. ${ }^{9}$

\section{c) Restorative Justice}

Crimes that do not cause unrest and do not result in social conflict as well as relatively minor offenses that carry a penalty of less than 5 years or a fine or non-recidivist criminals. These types of crimes in Indonesia can be resolved through RJ whose implementation is under the authority of the police, prosecutors and judges.

Data from the South Sulawesi Regional Police (Polda) in 2016 were 14,080 cases, RJ 175, (263 cases of defamations)/RJ 3, in 2017 as many as 23,523 cases and RJ 200, (423 cases of defamations/RJ 4), in 2018 as many as 25,121 cases, RJ 154, (204 cases of defamation/RJ 3), in 2019 as many as 16,730 cases, RJ 2,267, (325 cases of defamation/RJ 156), in 2020 as many as 14,459 cases, RJ 1,908, 231 crimes of defamation/ RJ 119.

The prosecutor's data for 2019-2020 the prosecutor's office has stopped prosecuting cases based on RJ with details of 97 cases of individual victims, 4 cases of corporate victims spread over 27 provinces and 70 regencies/cities. ${ }^{10}$ The prosecutor's data for 2020-August 2021, the settlement of crimes through RJ as many as 304 cases. $^{11}$

\footnotetext{
${ }^{1}$ Nieto, V. G. (2020). Defamation as a Language Crime-A Sociopragmatic Approach to Defamation Cases in the High Courts of Justice of Spain. JLL, 9, 1. http://dx.doi.org/10.14762/j11.2020.001

${ }^{2}$ Nur, R., Dharmawati, D., Bakhtiar, H. S., \& Siliwadi, D. N. (2020). Insult and Defamation through Information Technology: Indonesia Perspective. International Journal on Emerging Technologies, 11(4), 373-378.

${ }^{3}$ Anstey, B. J. (2017). Criminal Defamation and Reputation as 'Honour': a cross-jurisdictional perspective. Journal of Media Law, 9(1), 132153. https://doi.org/10.1080/17577632.2017.1311467

https://kabar24.bisnis.com/read/20210310/16/1366254/polri-pelaporan-uu-ite-cenderung-meningkat-sejak-20182020\#: : text=Selain $\% 20 \mathrm{itu} \% 2 \mathrm{C} \% 20$ Polri\%20mencatat $\% 20 \mathrm{kasus}, 1.794 \% 201$ aporan $\% 20$ polisi $\% 20$ pada $\% 202020$. Accessed on 28 April 2021 https://www.tribunnews.com/nasional/2021/02/22/surat-telegram-kapolri-kasus-pencemaran-nama-baik-fitnah-dan-penghinaan-tidakditahan, Accessed on 28 April 2021

${ }^{6}$ Data: Directorate of General Crime and Investigation of the South Sulawesi Police, January 2021.

Veeder, V. V. (1903). The History and Theory of the Law of Defamation. I. Columbia Law Review, 3(8), 546-573. https://www.jstor.org/stable/1110000

${ }^{8}$ Utrecht, E. (2000). Hukum Pidana II. Surabaya: Indonesia, p.7

${ }^{9}$ Kanaitang, O. (2019). Kedudukan Delik Aduan Dalam Delik-Delik Penghinaan Yang Diatur Dalam Kitab Undang-Undang Hukum Pidana. Lex Crimen, 8(7).

${ }^{10}$ Hari Setiyono Kepala Pusat Penerangan Kejaksaan Agung, https://kabar24.bisnis.com/read/20201026/16/1310024/pertimbangkanrestorative-justice-kejaksaan-hentikan-101-perkara-pidana, accessed on 12 November 2020.

${ }^{11}$ ST. Burhanuddin. Loc.cit.
} 
The author found 917 criminal decisions at all levels of courts that implemented RJ with details as many as 761 decisions at the district court level and as many as 90 decisions at the appeals level (high court) and as many as 66 decisions at the Supreme Court level with details as many as 59 cassation decisions and 7 review decisions. Return. These cases are domestic violence, sexual intercourse or obscenity against children, violence against children, embezzlement, fraud, theft, abuse, activities that cause road function disruption, motor vehicle driver negligence, and defamation. ${ }^{1}$ The settlement through RJ of the crime was not carried out under the authority of the court, but the results of RJ were used as the basis for mitigating considerations in the judge's decision, in the form of a probationary / conditional sentence.

Police and prosecutors open up space for more crimes to be solved through RJ whose execution is under their authority. The court gave restrictions on the settlement of crimes through RJ whose implementation was under the authority of the court, but the judge acknowledged that the implementation of RJ was carried out outside the court's authority. Walgrave's logic contradicts that there is no crime so gruesome as to hinder RJ's proceedings, it's just that it takes longer before an RJ meeting can take place. ${ }^{2}$ The implementation of RJ under the official authority of law enforcement is still partial and has not been integrated into a comprehensive criminal justice system. This article offers an integrated model of the application of RJ in the Indonesian criminal justice system as a whole.

\section{d) Concept of Restorative Justice}

The protection of the legal interests of victims in RJ is different from the mechanism of retributive justice, where attention and protection of the legal interests of victims of crime in the Criminal Procedure Code has not been maximized/sufficient. ${ }^{3}$ It is recognized that the retributive justice system prioritizes the protection of the legal interests of suspects, defendants and convicts ${ }^{4}$ rather than the protection of the legal interests of victims of crime.

Victims of crime as the party most harmed by the crime. The form of protection for the legal interests of the victims given is the mechanism and procedure for the RJ program carried out according to the wishes of the victim, as well as the results achieved. Although of course it does not ignore the legal interests of the perpetrators.

The form of legal protection for victims of crime in the settlement of criminal cases through RJ is the harmonization of the relationship between victims, perpetrators and their families. In order to realize the harmonization of the relationship through RJ, various things must be done, namely sincere acknowledgment and regret from the perpetrator for the mistake and a sincere promise not to repeat the mistake accompanied by an apology and full of generosity by the victim forgiving the perpetrator.

The results of Kathleen Daly's empirical research found that victims doubted the sincerity of the perpetrator's apology and only $27 \%$ believed it. ${ }^{5}$ The results of Dignan's empirical research found that only $61 \%$ of perpetrators apologized on the grounds that they were truly sorry. ${ }^{6}$ Other studies in Australia and the UK found that the percentage of victims who forgive their perpetrators is $30-70 \%{ }^{7}$, as well as in Northern Ireland that $80 \%$ of victims forgive their perpetrators ${ }^{8}$ and in New Zealand about half of juvenile offenders feel they have received forgiveness. ${ }^{9}$ Before the perpetrator of a crime apologizes to the victim, the perpetrator must first forgive himself accompanied by sincere and sincere regret for the crime committed.

$\mathrm{RJ}$ is used by society for sustainable peace and harmony in order to eradicate the evil and criminal thoughts of society. ${ }^{10} \mathrm{RJ}$ plays a role in rapprochement and peace. ${ }^{11} \mathrm{RJ}$ has its roots in traditional values in traditional

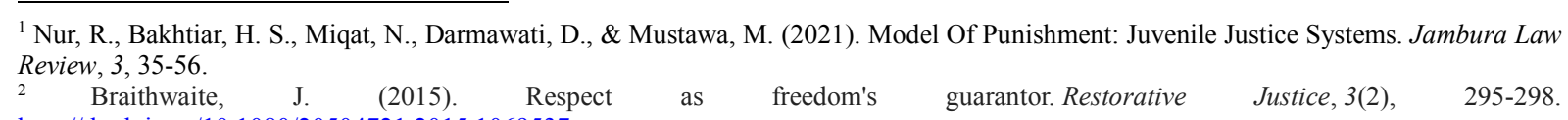
http://dx.doi.org/10.1080/20504721.2015.1069537.

${ }^{3}$ Yuliartini, N. P. R. (2015). Kedudukan Korban Kejahatan Dalam Sistem Peradilan Pidana Di Indonesia Berdasarkan Kitab Undang-Undang Hukum Acara Pidana (KUHAP). Jurnal Komunikasi Hukum (JKH), 1(1). See to, Koordinator Puslitbang Mahkamah Agung Republik Indonesia. https://bldk.mahkamahagung.go.id/id/puslitbang-id/dok-keg-puslitbang-id/731-perlindungan-korban-dalam-sistem-peradilanpidana-ditinjau-dari-perspektif-restoratif-justice.html, accessed on 7 October 2021.

${ }^{4}$ Muhadar, et al. (2010). Perlindungan Saksi dan Korban dalam Sistem Peradilan Pidana. Surabaya: Putra Media Nusantara, p. 50.

${ }^{5}$ Ibid. p. 229

${ }^{6}$ Dignan, J. (2004). Understanding victims and restorative justice. McGraw-Hill Education (UK). p. 142

${ }^{7}$ Sherman, L. W., Strang, H., Angel, C., Woods, D., Barnes, G. C., Bennett, S., \& Inkpen, N. (2005). Effects of face-to-face restorative justice on victims of crime in four randomized, controlled trials. Journal of experimental criminology, 1(3), $367-395$. https://doi.org/10.1007/s11292-005-8126-y.

${ }^{8}$ Campbell, C., Devlin, R., O’Mahony, D., Doak, J., Jackson, J., Corrigan, T., \& McEvoy, K. (2005). Evaluation of the Northern Ireland Youth Conference Service (NIO research and statistical series: Report No. 12). Northern Ireland Office, Statistics and Research Branch.

${ }^{9}$ Maxwell, G. M., Kingi, V. M., Robertson, J. P., Morris, A., Cunningham, C., \& Lash, B. (2004). Achieving effective outcomes in youth justice. Wellington: Ministry of Social Development.

${ }^{10}$ Amjad, S., \& Riaz, N. (2019). The concept and scope of restorative justice system: Explaining history and development of the system for the immediate need of society. International Journal of Law, September.

${ }^{11}$ Emanuela Biffi. (2021) The Potential of Restorative Justice in Cases of Violent Extremism and Terrorism, European Commission Documents. Luxembourg: Publications Office of the European Union. https://europa.eu/european-union/index en. accessed on 19 June 2021. See also, Sainuddin, L., Magassing, A. M., Sakharina, I. K., \& Bakhtiar, H. S. (2017). Legal Analysis of Crime Terrorism and Counter Terrorism Strategy. International Journal of Advanced Research (IJAR), 5(7), 93-95. 
societies such as the value of balance, harmonization and peace in society. ${ }^{1}$ Family culture in Indonesia is very supportive of the RJ program. One of the values of family culture is to forgive mistakes. Indonesian people are easier to forgive the mistakes of others, and this is the main capital in solving crimes through RJ.

The sincerity of the perpetrator's apology and the victim's forgiveness are the main keys that RJ can continue to do, forgiveness cannot be forced on the victim. ${ }^{2}$ Without it, the RJ program cannot continue. Therefore, the main focus in seeking is forgiveness. Martin E. Blyth's view differs that forgiveness should not be aimed at RJ, but is considered a gift ${ }^{3}$, but it is acknowledged that there is a lack of studies related to forgiveness in RJ. ${ }^{4}$

If the victim sincerely forgives the perpetrator, then that is a form of recovery for the victim who was previously angry, resentful and afraid of the perpetrator, becoming acquainted with and prejudiced against the perpetrator. The sincerity of the perpetrator's apology reduces or eliminates the guilt of the perpetrator to the victim and can increase the perpetrator's confidence to be able to interact well in society. The sincerity of the victim's forgiveness also affects the mental burden of the perpetrator, because with the forgiveness of the victim, the perpetrator of a crime of defamation or defamation feels that he has been able to take responsibility and restore the victim's condition, this is important in order to build harmonization of the relationship between the victim and the perpetrator and his family.

Harmonization of relations between victims and perpetrators and their families is one form of recovery for victims and perpetrators. ${ }^{5}$ Recovery is realized through peace between the victim and the perpetrator, so that the relationship between the victim and the perpetrator and their family is restored and balance is achieved. The application of RJ in this case became the basis for an Indonesian court judge to impose a suspended sentence on the perpetrator. Victims and perpetrators feel protected and recovered from their inner wounds and relieve the perpetrator's guilt. The judge used RJ's consideration as an excuse to reduce the sentence to the perpetrator.

The idea emerged through RJ which is expected to be able to contribute in realizing the harmony of human life. The birth of the crime of defamation certainly raises social imbalances in society, because it involves the reputation and honor of people. Victims of crimes of defamation, will get a negative stigma in the community. The negative stigma against the victim certainly affects the association of the victim in the community. This negative stigma cannot be recovered only by punishing criminals through a retributive justice system.

RJ's idea was born with the concept of recovery which does not only restore the relationship between the victim and the perpetrator and their family, but more than that, namely to restore the condition of the victim of a crime to the reputation or honor of the person by rebuilding the victim's social relationship in the community that had been disturbed by the crime. The victim's negative stigma in the community as a result of the crime of defamation is an important part of recovery in the RJ program. Perpetrators of insulting crimes assisted by the community in the RJ program are responsible for restoring negative stigma against victims of insulting crimes in community social interactions.

Trust in the good name, reputation and honor of the victim in the community must be rebuilt, so that social imbalances resulting from the occurrence of crimes of defamation can be recovered. One way to recover the negative stigma in question is to convey to the public in general and specifically within the victim's social circle, that words or writings that contain content that damage the reputation and honor of the victim committed by the perpetrator are not true, accompanied by deep regret and apology. of the perpetrator for his actions. Apologies and deep regrets for the perpetrator's mistakes can be conveyed directly to the community in the victim's social environment and workplace or through mass or electronic media or in other places that can be heard by the public.

\section{e) Model of Restorative Justice Integration}

The RJ program model in each stage of the criminal justice process is different, although the objectives are the same. ${ }^{6}$ The Indonesian criminal justice system is divided into 4 (four) stages, namely (1) the investigation and investigation stages; (2) prosecution stage; (3) the stage of the trial court examination; (4) the stages of implementing the judge's decision. The police have duties and responsibilities in the field of investigation and investigation. The Prosecutor's Office has duties and responsibilities in the field of prosecution. Courts have duties and obligations to examine, hear and decide cases. Correctional institutions have the duty and obligation to provide guidance to prisoners.

\footnotetext{
${ }^{1}$ Zulfa, E. A. (2010). Keadilan Restoratif dan Revitalisasi Lembaga Adat di Indonesia. Indonesian Journal of Criminology, 4199.

${ }^{2}$ Richards, K. (2010). Police-referred restorative justice for juveniles in Australia. Trends and issues in crime and criminal justice, (398), 1-8. ${ }^{3}$ Blyth, M. N. (2016). Introduction to the Section on Restorative Justice (OJLR_-Jan 2016). Oxford Journal of Law and Religion, 5(1), 4953.

${ }^{4}$ Suzuki, M., \& Jenkins, T. (2020). The role of (self-) forgiveness in restorative justice: Linking restorative justice to desistance. European Journal of Criminology, 1477370819895959.

${ }^{5}$ Syukri Akub, A.M, and Sutiawati. (2018). Keadilan Restoratif (Restorative Justice) Perkembangan, Program Serta Prakteknya di Indonesia dan Beberapa Negara. Yogyakarta: Litera, p. 29.

${ }^{6}$ Van Ness, D. (2003). Proposed basic principles on the use of restorative justice: Recognising the aims and limits of restorative justice. Restorative justice and criminal justice: Competing or reconcilable paradigms, 157-176.
} 
The proposed model of RJ's integration into the Indonesian criminal justice system in this paper, specifically for crimes of defamation or defamation which are crimes of complaint, goes through the four stages mentioned above, but this paper does not discuss the integration of RJ in correctional institutions. This integration thinking is based on the idea that RJ should be carried out under the auspices of the criminal justice authorities $^{1}$, as in Norway and Finland implementing RJ in the formal justice system called the RJ justice system $^{2}$. Limiting or separating RJ from criminal justice or retributive justice is very difficult. ${ }^{3}$

The integration of $\mathrm{RJ}$ at the stage of investigation and investigation is carried out through the authority of the investigator or investigator to take other actions according to the law that is responsible. One of the other forms of action is to solve crimes through RJ. At this stage the RJ model must be approved by the victim and perpetrator and they want to participate ${ }^{4}$, the police can be a facilitator ${ }^{5}$ and community leader or elders ${ }^{6}$, religious leaders ${ }^{7}$ or spiritual leaders ${ }^{8}$, traditional leaders ${ }^{9}$, trained mediators ${ }^{10}$ can be an option for mediators. The determination of the mediator is determined by the agreement of the victim and the perpetrator and of course must be neutral and independent. A trusted and fair RJ process and balanced ${ }^{11}$ participation between victims and perpetrators and their families ${ }^{12}$, meeting the needs of victims based on the ability of the perpetrators to take responsibility with the help of their families, guarantors, friends, or fellow citizens for reparation of victims ${ }^{13}$, as well as reforming the perpetrators by rebuilding morals and his social feelings ${ }^{14}$, instead of humiliating, demeaning the perpetrator and damaging his social ties ${ }^{15}$ are the core of implementing RJ.

The settlement of the crime of defamation through RJ which is successfully carried out in the investigation or investigation stage, then the agreement between the victim and the perpetrator is written in a peace agreement letter witnessed by his family and the mediator and facilitator. The victim then makes a statement revocation of the complaint. The investigator/investigator examines the victim and the perpetrator regarding the veracity of the reconciliation letter and the letter of revocation of the complaint through an additional Investigation Report (BAP). The two letters (the peace agreement letter and the certificate of revocation of the complaint) are important because they form the basis for the lead investigator to issue an Investigation Termination Order (SP3) and followed up by the investigator issuing an Investigation Termination Decision Letter (SKPP) or the investigator issuing an Investigation Termination Decision Letter (SKPP) with the reason for the settlement is through RJ and the case is completed. If peace and agreement between the victim and the perpetrator is not reached, the police will continue the investigation process.

The integration of RJ in the criminal justice system at the prosecution stage is relatively the same as the investigation and investigation stage. The person in charge of the prosecution is the prosecutor. If the RJ process at the investigation and investigation stage does not succeed in finding an agreement or peace between the victim and the perpetrator, then at this stage the prosecution is turned into a dialogue to create an agreement ${ }^{16}$, the

\footnotetext{
${ }^{1}$ Von Hirsch. Op.Cit

2 Albrecht, B. (2010). Multicultural challenges for restorative justice: Mediators' experiences from Norway and Finland. Journal of Scandinavian Studies in Criminology and Crime Prevention, 11(1), 3-24.

${ }^{3}$ Shapland, J. (2003). Restorative justice and criminal justice: Just responses to crime. Restorative justice and criminal justice: Competing or reconcilable paradigms, $195-218$

${ }^{4}$ Wilson, D. B. Op. Cit.

${ }^{5}$ Larsson, B., Schofield, G., \& Biggart, L. (2018). The challenges for good practice in police-facilitated restorative justice for female offenders. Int'l J. Restorative Just., 1, 33. See also, Sirait, T. Y., \& Cahyaningtyas, I. (2019). Restorative Justice Approach In The Settlement Of Children's Cases In Indonesia. Legality: Jurnal Ilmiah Hukum, 27(2), 232-241. See also, Bakhtiar, H. S., Sofyan, A. M., \& Haeranah, H. (2019). Criminal Justice System of Children in Indonesia. IOSR Journal Of Humanities And Social Science (IOSR-JHSS) Volume, $24,01-07$. See also, Young, R., \& Hoyle, C. (2003). New, improved police-led restorative justice. A. von Hirsch, J. Roberts, AE Bottoms, K. Roach \& Schiff, M.(eds). Restorative justice and criminal justice: Competing or reconcilable paradigms.

${ }^{6}$ Mok, L. W., \& Wong, D. S. (2013). Restorative justice and mediation: diverged or converged?. Asian Journal of Criminology, 8(4), 335347.

${ }^{7}$ Islam, M. J., Suzuki, M., Mazumder, N., \& Ibrahim, N. (2018). Challenges of implementing restorative justice for intimate partner violence: An Islamic perspective. Journal of Religion \& Spirituality in Social Work: Social Thought, 37(3), $277-301$.

${ }^{8}$ Van Wormer, K. (2003). Restorative justice: a model for social work practice with families. Families in Society, 84(3), 441-448.

${ }^{9}$ Elmayanti, E., Deliana, H. E., \& Rasudin, N. (2020, May). Settlement of Criminal Cases Through Customary Institutions Using the Concept of Restorative Justice. In Riau Annual Meeting on Law and Social Sciences (RAMLAS 2019) (pp. 144-146). Atlantis Press.

$10 \mathrm{http}: / /$ restorativejustice.org/restorative-justice/about-restorative-justice/tutorial-intro-to-restorative-justice/lesson-3-programs/victimoffender-mediation/\#sthash.4hVznTBR.dpbs, accessed on 20 April 2021

${ }^{11}$ Hoyle, C., \& Batchelor, D. (2018). Making room for procedural justice in restorative justice theory. The International Journal of Restorative Justice, Issue 2, https://doi.org/10.5553/IJRJ/258908912018001002001.

12 Hafrida, H. (2019). Restorative Justice in Juvenile Justice to Formulate Integrated Child Criminal Court. Jurnal Hukum dan Peradilan, 8(3), 439. See also, Nur, R., \& Bakhtiar, H. S. (2020). The Imposition of Sanctions for Children. Hasanuddin Law Review, 6(2), 165-171. See also, Amjad, S., \& Riaz, N. (2019). The concept and scope of restorative justice system: Explaining history and development of the system for the immediate need of society. International Journal of Law, Vol 5, Issue 5.

${ }^{13}$ Von Hirsch. Op.Cit

${ }^{14}$ Hermann, D. H. Op.Cit. See also, Ringgi, D., Musliana, A., Sainuddin, L., \& Bakhtiar, H. S. (2017). Role of Law in Dealing with the Cyber Crime and Social Change. International Journal of Humanities and Social Science Invention.

${ }^{15}$ Goodstein, J., \& Aquino, K. (2010). And restorative justice for all: Redemption, forgiveness, and reintegration in organizations. Journal of Organizational Behavior, 31(4), 624-628.

${ }^{16}$ Juhari. (2018). Restorative Justice in The Renewal of Criminal Law in Indonesia, International Journal of Business, Economics and Law,
} 
public prosecutor can become a facilitator of crime resolution through RJ. At this stage the prosecutor may offer the victim and the perpetrator a different mediator in the RJ process at the stage of investigation and investigation. If an agreement and peace between the victim and the perpetrator is reached, a peace agreement letter is made and accompanied by a certificate of revocation of the complaint from the victim. The two documents became the basis for the leadership of the public prosecutor to issue an Order for Termination of Prosecution (SP3) and continued by the public prosecutor issuing a Decision on Termination of Prosecution (SKPP) on the grounds that the case was settled through RJ and the case was completed. If an agreement and peace are not reached, the case will proceed to court.

The description of RJ's integration into the Indonesian criminal justice system at the stage of trial court examination, the authors divide into 2 (two) schemes, namely the stage of examining the indictment and the stage of proof. Especially for crimes of defamation or defamation which are crimes of complaint, the judge in every case examination should offer to the defendant and the victim to settle the case through RJ. If the victim and the defendant are willing, the judge can become a facilitator or if it is agreed by the victim and the defendant the judge can become a mediator or the parties according to the previous description are the choice to become a mediator.

If the victim and the defendant through the settlement of RJ agree to make peace, then it is written in a peace agreement letter and the victim makes a certificate of revocation of the complaint. The two documents were submitted to the judge in a court session to be used as a basis for consideration in issuing a decision. If the examination of the case is only at the stage of examining the indictment before entering the evidentiary trial, the judge may give consideration to the settlement of the case through RJ with the decision that the interlocutory indictment cannot be accepted. If the examination of the case has reached the stage of the evidentiary trial, then the settlement of the case through RJ can be considered by the judge to issue a final decision that the public prosecutor's demands cannot be accepted.

The design of the integration model for the settlement of crimes of defamation through RJ in the Indonesian criminal justice system is described as follows:

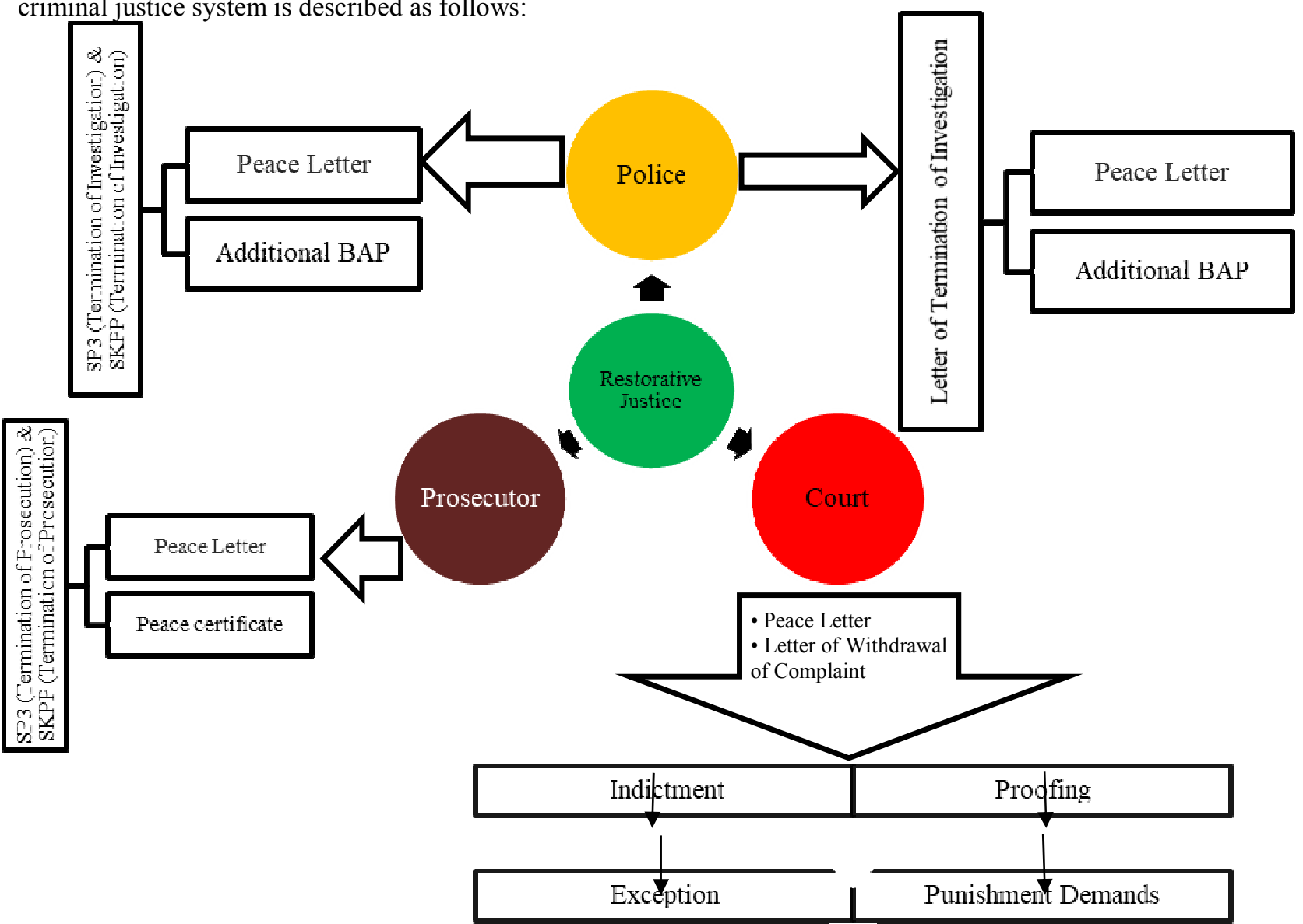




\section{f) Control}

The author knows that no system is perfect. Supervision is the best guarantee of how the system can be run properly. The integration of RJ in the Indonesian criminal justice system still requires supervision. The author divides supervision into 2 (two) forms of internal control and external supervision.

Internal supervision is carried out by the leadership of each law enforcement agency. The implementation of RJ by the police is directly supervised by the head of the police in each region and the highest supervision is in the hands of the Head of the Indonesian Police. Supervision at the prosecutor's office is also carried out by the head of the prosecutor's office in each region and the highest supervision is in the hands of the Attorney General. In court, the Chief Justice of each region supervises the supervision and the highest supervision is the Chief Justice of the Supreme Court. They are tasked with supervising the implementation of RJ within their respective institutions.

The form of external supervision of the implementation of $\mathrm{RJ}$ in the criminal justice system in Indonesia is carried out through pretrial. Pretrial is a legal tool used to examine the implementation of coercive measures by the police and prosecutors, including the termination of investigations and prosecutions of cases. As previously explained, the legal means used to integrate $\mathrm{RJ}$ in the Indonesian criminal justice system is the termination of investigation, investigation or prosecution of cases. The basis for the termination is a letter of peace agreement between the victim and the perpetrator. Testing the validity or illegitimacy of the termination of an investigation or prosecution of a case on the grounds that the application of RJ is submitted through a district court in the jurisdiction of the police or the prosecutor who terminates the investigation or prosecution of the case.

\section{Conclusion}

The resolution of the problem of crime through restorative justice with the concept of recovery arises from criticism of the retributive crime settlement model which prioritizes punishment. The Indonesian criminal justice system applies the retributive concept, but in various cases it also applies the restorative justice concept. These two models are different, but can be integrated into one system. The integration of the settlement of restorative justice crimes with retributive in this paper, specifically on the crime of defamation which is a crime of complaint. The integration of restorative justice into the criminal justice system can be carried out at every stage of law enforcement. The stages of investigation and integration investigation are carried out through the authority of investigators and investigators to take other actions according to responsible law. Investigators or investigators can become facilitators of the implementation of restorative justice programs, if a peace agreement is reached between the victim and the perpetrator, then it is stated in a letter of peace agreement between the victim and the perpetrator. The victim then made a letter of revocation of the complaint. These two documents become the basis for investigators or investigators to carry out additional examinations and issue a decree to terminate the investigation or case investigation on the grounds of settlement through restorative justice. Integration in the prosecution stage is relatively the same as the investigation and investigation stage, the prosecutor can become a facilitator. If there is a peace agreement between the victim and the perpetrator, then it is written in a peace agreement letter and the victim makes a certificate of revocation of the complaint. The two documents became the basis for the public prosecutor to issue a letter of termination of prosecution on the grounds of settlement through restorative justice. The stages of the court's integration of restorative justice into the system are carried out by way of case settlement documents through restorative justice, namely a peace agreement letter between the victim and the perpetrator and a certificate of revocation of complaints from the victim which becomes the basis for the judge to issue a decision that the indictment cannot be accepted or the final decision on the demands of the public prosecutor. not acceptable. In order to carry out the integration of restorative justice into the Indonesian criminal justice system, it is necessary to control both internal control and external control. Internal control is carried out by each head of law enforcement agencies in every stage of law enforcement. External control can be exercised through pretrial means.

\section{References}

Albrecht, B. (2010). Multicultural challenges for restorative justice: Mediators' experiences from Norway and Finland. Journal of Scandinavian Studies in Criminology and Crime Prevention, 11(1), 3-24.

Akub, M. S., \& Asis, A. (2020). Perlindungan Hukum Terhadap Saksi Pelapor dalam Tindak Pidana Korupsi. Amanna Gappa, Vol. 28 No. 2, 2020.

Amjad, S., \& Riaz, N. (2019). The concept and scope of restorative justice system: Explaining history and development of the system for the immediate need of society. International Journal of Law, September.

Anstey, B. J. (2017). Criminal Defamation and Reputation as 'Honour': a cross-jurisdictional perspective. Journal of Media Law, 9(1), 132-153. https://doi.org/10.1080/17577632.2017.1311467

Azisa, N. (2015). Kompensasi Dan Restitusi Bagi Korban Kejahatan Sebagai Implementasi Prinsip Keadilan. Disertasi Program Pascasarjana Universitas Hasanuddin. Makassar.

Bakhtiar, H. S., Sofyan, A. M., \& Haeranah, H. (2019). Criminal Justice System of Children in Indonesia. IOSR 
Journal Of Humanities And Social Science (IOSR-JHSS) Volume, 24, 01-07.

Bedau, H. A. (1978). Retribution and the Theory of Punishment. The Journal of Philosophy, 75(11), 601-620.

Blyth, M. N. (2016). Introduction to the Section on Restorative Justice (OJLR-Jan 2016). Oxford Journal of Law and Religion, 5(1), 49-53.

Braithwaite, J. (2015). Respect as freedom's guarantor. Restorative Justice, 3(2), 295-298. http://dx.doi.org/10.1080/20504721.2015.1069537.

Britto, S., \& Reimund, M. E. (2013). Making space for restorative justice in criminal justice and criminology curricula and courses. Contemporary Justice Review, 16(1), 150-170. https://doi.org/10.1080/10282580.2013.769301.

Brown, S. P. (1998). The moral justification of retributive punishment by reference to the notion of balance, University of Sheffield.

Campbell, C., Devlin, R., O’Mahony, D., Doak, J., Jackson, J., Corrigan, T., \& McEvoy, K. (2005). Evaluation of the Northern Ireland Youth Conference Service (NIO research and statistical series: Report No. 12). Northern Ireland Office, Statistics and Research Branch.

Christie, N. (1977). Conflicts as property. The British journal of criminology, 17(1), 1-15. https://doi.org/10.1093/oxfordjournals.bjc.a046783.

Dignan, J. (2004). Understanding victims and restorative justice. McGraw-Hill Education (UK). p. 142.

Dignan, J. (2012). Restorative justice and the law: the case for an integrated, systemic approach. In Restorative justice and the law (pp. 188-210). http://www.antoniocasella.eu/restorative/Dignan_2002.pdf.

Dignan, J., \& Lowey, K. (2000). Restorative justice options for Northern Ireland: A comparative review. Belfast: Stationery Office. p. 49-56

Dignan, J., \& Marsh, P. (2001). Restorative justice and family group conferences in England: current state and future prospects. Restorative Justice for Juveniles Conferencing, Mediation and Circles, 85-101.

Dzur, A. W., \& Olson, S. M. (2004). The value of community participation in restorative justice. Journal of social philosophy, 35(1), 91-107.

Edgar, K., \& Newell, T. (2006). Restorative justice in prisons: A guide to making it happen. Waterside Press.

Elmayanti, E., Deliana, H. E., \& Rasudin, N. (2020, May). Settlement of Criminal Cases Through Customary Institutions Using the Concept of Restorative Justice. In Riau Annual Meeting on Law and Social Sciences (RAMLAS 2019) (pp. 144-146). Atlantis Press.

Emanuela Biffi. (2021) The Potential of Restorative Justice in Cases of Violent Extremism and Terrorism, European Commission Documents. Luxembourg: Publications Office of the European Union. https://europa.eu/european-union/index_en. accessed on 19 June 2021.

Goodstein, J., \& Aquino, K. (2010). And restorative justice for all: Redemption, forgiveness, and reintegration in organizations. Journal of Organizational Behavior, 31(4), 624-628.

Hafrida, H. (2019). Restorative Justice in Juvenile Justice to Formulate Integrated Child Criminal Court. Jurnal Hukum dan Peradilan, 8(3), 439.

Hart, H. L. A. (2008). Punishment and responsibility: Essays in the philosophy of law. Oxford University Press. p. 231.

Hermann, D. H. (2017). Restorative justice and retributive justice: An opportunity for cooperation or an occasion for conflict in the search for justice. Seattle J. Soc. Just., 16, 71.

Hill, T. E. (1999). Kant on wrongdoing, desert, and punishment. Law and Philosophy, 407-441. http://www.jstor.org/stable/3505232.

Hoyle, C., \& Batchelor, D. (2018). Making room for procedural justice in restorative justice theory. The International Journal of Restorative Justice, Issue 2, https://doi.org/10.5553/IJRJ/258908912018001002001.

Islam, M. J., Suzuki, M., Mazumder, N., \& Ibrahim, N. (2018). Challenges of implementing restorative justice for intimate partner violence: An Islamic perspective. Journal of Religion \& Spirituality in Social Work: Social Thought, 37(3), 277-301.

Johnstone, G. (2013). Restorative justice: Ideas, values, debates. Routledge. Published Willan Publishing, Culmcott House, Mill Street, Uffculme Cullompton, Devon, p. 12.

Juhari. (2018). Restorative Justice in The Renewal of Criminal Law in Indonesia, International Journal of Business, Economics and Law, Vol. 16, Issue 5 (August 2018), pp. 127-133, https://www.ijbel.com/vol-16august-2018-issue-5/.

Kanaitang, O. (2019). Kedudukan Delik Aduan Dalam Delik-Delik Penghinaan Yang Diatur Dalam Kitab Undang-Undang Hukum Pidana. Lex Crimen, 8(7).

Koritansky, P. (2005). Two theories of retributive punishment: Immanuel Kant and Thomas Aquinas. History of Philosophy Quarterly, 22(4), 319-338. http://www.jstor.org/stable/27745035.

Larsson, B., Schofield, G., \& Biggart, L. (2018). The challenges for good practice in police-facilitated restorative justice for female offenders. Int'l J. Restorative Just., 1, 33.

Llewellyn, J. (2013). Truth commissions and restorative justice. In Handbook of restorative justice (pp. 373-393). 
Portland, OR: Willan Publishing.

Lloyd, A., \& Borrill, J. (2020). Examining the effectiveness of restorative justice in reducing victims' posttraumatic stress. Psychological injury and law, 13(1), 77-89. https://doi.org/10.1007/s12207-019-09363-9.

lvement are victims looking for?. International Review of Victimology, 11(2-3), 259-274.

Maculan, E., \& Gil Gil, A. (2020). The Rationale and Purposes of Criminal Law and Punishment in Transitional Contexts. Oxford Journal of Legal Studies, 40(1), 132-157.

Marder, I. D. (2018). Restorative justice and the police: exploring the institutionalisation of restorative justice in two English forces. thesis the degree of Doctor of Philosophy, The University of Leeds School of Law Centre for Criminal Justice Studies Centre for Law and Social Justice, (Februari 2018).

Maxwell, G. M., Kingi, V. M., Robertson, J. P., Morris, A., Cunningham, C., \& Lash, B. (2004). Achieving effective outcomes in youth justice. Wellington: Ministry of Social Development.

Mok, L. W., \& Wong, D. S. (2013). Restorative justice and mediation: diverged or converged?. Asian Journal of Criminology, 8(4), 335-347.

Muhadar, et al. (2010). Perlindungan Saksi dan Korban dalam Sistem Peradilan Pidana. Surabaya: Putra Media Nusantara.

Nieto, V. G. (2020). Defamation as a Language Crime-A Sociopragmatic Approach to Defamation Cases in the High Courts of Justice of Spain. JLL, 9, 1. http://dx.doi.org/10.14762/j1l.2020.001

Nur, R., \& Bakhtiar, H. S. (2020). The Imposition of Sanctions for Children. Hasanuddin Law Review, 6(2), $165-$ 171.

Nur, R., Dharmawati, D., Bakhtiar, H. S., \& Siliwadi, D. N. (2020). Insult and Defamation through Information Technology: Indonesia Perspective. International Journal on Emerging Technologies, 11(4), 373-378.

Olayode, A. (2017). Back to the Past: The (Re) Integration of Restorative Justice into the Nigerian Criminal Justice System.

Oppenheimer, H. (1913). The rationale of punishment (Vol. 1). Thesis approved for the degree of Doctor of Literature in the University of London, The University of London Press, Ltd. By Hodder and Stoughton, Warwick Square, E.G. 1913, p. 221-224

Palermo, P. G., del Castillo, F., \& Fraiman, R. (2019). Restorative Justice in Uruguay: A Change of Lenses in a Reform of Criminal Justice?. European Journal for Security Research, 4(1), 131-147.

Poplawsky, J. P. (2017). Learning to Heal: The Impact of a Restorative Justice Program on Crime Victims. Doctor of Philosophy University of The Incarnate Word.

Richards, K. (2010). Police-referred restorative justice for juveniles in Australia. Trends and issues in crime and criminal justice, (398), 1-8.

Shapland, J. (2003). Restorative justice and criminal justice: Just responses to crime. Restorative justice and criminal justice: Competing or reconcilable paradigms, 195-218.

Sherman, L. W., Strang, H., Angel, C., Woods, D., Barnes, G. C., Bennett, S., \& Inkpen, N. (2005). Effects of face-to-face restorative justice on victims of crime in four randomized, controlled trials. Journal of experimental criminology, 1(3), 367-395. https://doi.org/10.1007/s11292-005-8126-y.

Sirait, T. Y., \& Cahyaningtyas, I. (2019). Restorative Justice Approach In The Settlement Of Children's Cases In Indonesia. Legality: Jurnal Ilmiah Hukum, 27(2), 232-241.

Smith, A. (2013). Mainstreaming Restorative Justice in South Australia's Criminal Justice System: A Response to the Over-Representation of Indigenous Offenders. The ANU Undergraduate Research Journal, 169.

ST. Burhanuddin. (2021). Hukum Berdasarkan Hati Nurani (Sebuah Kebijakan Penegakan Hukum Berdasarkan Keadilan Restoratif). Pidato Pengukuhan Guru Besar Tidak Tetap Universitas Jenderal Soedirman. Purwokerto. (10 September 2021).

Suzuki, M., \& Jenkins, T. (2020). The role of (self-) forgiveness in restorative justice: Linking restorative justice to desistance. European Journal of Criminology, 1477370819895959.

Syukri Akub, A.M, and Sutiawati. (2018). Keadilan Restoratif (Restorative Justice) Perkembangan, Program Serta Prakteknya di Indonesia dan Beberapa Negara. Yogyakarta: Litera, p. 29.

Utrecht, E. (2000). Hukum Pidana II. Surabaya: Indonesia.

Van Ness, D. (2003). Proposed basic principles on the use of restorative justice: Recognising the aims and limits of restorative justice. Restorative justice and criminal justice: Competing or reconcilable paradigms, 157176.

Van Wormer, K. (2003). Restorative justice: a model for social work practice with families. Families in Society, 84(3), 441-448.

Veeder, V. V. (1903). The History and Theory of the Law of Defamation. I. Columbia Law Review, 3(8), $546-573$. https://www.jstor.org/stable/1110000

Von Hirsch, A., Roberts, J. V., Bottoms, A. E., Roach, K., \& Schiff, M. (Eds.). (2003). Restorative justice and criminal justice: Competing or reconcilable paradigms. Bloomsbury Publishing.

Wenzel, M., Okimoto, T. G., Feather, N. T., \& Platow, M. J. (2008). Retributive and restorative justice. Law and 
human behavior, 32(5), 375

Wilson, D. B., Olaghere, A., \& Kimbrell, C. S. (2018). Effectiveness of restorative justice principles in juvenile justice: A meta-analysis. Inter-university Consortium for Political and Social Research.

Witvliet, C. V., Worthington, E. L., Root, L. M., Sato, A. F., Ludwig, T. E., \& Exline, J. J. (2008). Retributive justice, restorative justice, and forgiveness: An experimental psychophysiology analysis. Journal of Experimental Social Psychology, 44(1), 10-25.

Wood, W. R., \& Suzuki, M. (2016). Four challenges in the future of restorative justice. Victims \& Offenders, 11(1), 149-172. https://doi.org/10.1080/15564886.2016.1145610.

Young, R., \& Hoyle, C. (2003). New, improved police-led restorative justice. A. von Hirsch, J. Roberts, AE Bottoms, K. Roach \& Schiff, M.(eds). Restorative justice and criminal justice: Competing or reconcilable paradigms.

Yuliartini, N. P. R. (2015). Kedudukan Korban Kejahatan Dalam Sistem Peradilan Pidana Di Indonesia Berdasarkan Kitab Undang-Undang Hukum Acara Pidana (KUHAP). Jurnal Komunikasi Hukum $(J K H), 1(1)$.

Zedner, L. (1994). Reparation and retribution: Are they reconcilable. Mod. L. Rev., 57, 228.

Zehr, H. (1990). Changing Lenses: A New Focus for Crime and Justice Harrisonburg, VA.

Zehr, H. (2015). The little book of restorative justice: Revised and updated. Simon and Schuster. Pennsylvania: Intercourse.

Zulfa, E. A. (2010). Keadilan Restoratif dan Revitalisasi Lembaga Adat di Indonesia. Indonesian Journal of Criminology, 4199.

Directorate of General Crime and Investigation of the South Sulawesi Regional Police, 2021.

Hari Setiyono Kepala Pusat Penerangan Kejaksaan Agung, https://kabar24.bisnis.com/read/20201026/16/1310024/pertimbangkan-restorative-justice-kejaksaanhentikan-101-perkara-pidana, accessed on 12 November 2020

$\mathrm{http}$ //restorativejustice.org/restorative-justice/about-restorative-justice/tutorial-intro-to-restorative-justice/lesson3-programs/victim-offender-mediation/\#sthash.4hVznTBR.dpbs, accessed on 20 April 2021

http://sdp.ditjenpas.go.id/sdp_website/, accessed on 20 April 2021.

https://kabar24.bisnis.com/read/20210310/16/1366254/polri-pelaporan-uu-ite-cenderung-meningkat-sejak-20182020\#: :text=Selain\%20itu\%2C\%20Polri\%20mencatat\%20kasus, $1.794 \% 20$ laporan\%20polisi\%20pada\%20 2020. Accessed on 28 april 2021.

https://kabar24.bisnis.com/read/20210310/16/1366254/polri-pelaporan-uu-ite-cenderung-meningkat-sejak-2018 2020\#: :text=Selain\%20itu\%2C\%20Polri\%20mencatat\%20kasus, $1.794 \% 20$ laporan $\% 20$ polisi\%20pada $\% 20$ 2020. Accessed on 28 April 2021

ICCLR, (2020), Restorative Justice Principles and the Criminal Justice Process, https://icclr.org/2020/05/25/restorative-justice-principles-and-the-criminal-justice-process/, accessed on 18 April 2021.

Koordinator Puslitbang Mahkamah Agung Republik Indonesia. https://bldk.mahkamahagung.go.id/id/puslitbangid/dok-keg-puslitbang-id/731-perlindungan-korban-dalam-sistem-peradilan-pidana-ditinjau-dari-perspektifrestoratif-justice.html, accessed on 7 October 2021.

Makassar High/State Court, 2018, Makassar High Court Annual Report 2018

Supreme Court of the Republic of Indonesia 2018,

Supreme Court Annual Report 2018, 